\title{
Doing Business and Role of Government for Entrepreneurship Development
}

\author{
Bir Bahadur Karki
}

\begin{abstract}
Doing business takes perspective of domestic primarily smaller companies and measure the regulation applying to them through their life cycle. The objective is regulation designed to be efficient accessible to all and simple in their implementation. Globally, doing business remain easiest in OECD high income economies. Out of 183 economies Singapore retains to top ranking or the ease of doing business whereas Nepal has ranked in 116. The main aims of one village one product (OVOP) and one Tambon one product $(O T O P)$ is to develop micro, small and medium enterprise at the grass root level and reduce unemployment problems and poverty alleviation. These programme are more or less based on public private partnership (PPP) policy and technique. Like, other country, Nepal has been adopted OVOP programme within 11 districts out of 75 districts, since 2006.
\end{abstract}

Keywords: doing business, regulation, entrepreneurship, poverty alleviation, OVOP

\section{Background}

Nepal is the richest country in the world in terms of natural resources hydropower, herbal and mountain peaks. But, due to lack of effective management, proper planning and controlling and appropriate business environment such resources are not utilized and used for economic development of nations.

Unemployment is the macroeconomics problems that affect people most directly and severely. For most people the loss of a job means a reduced living standard and psychological distress. It is no surprise that unemployment is a frequent topic of political debate and that politician often claim that their proposed policies would help create jobs.

Economists study unemployment to identity its causes and to help improve the public policies that affect the unemployed. Some of these policies such as job training program assist people in finding employment. By showing the effects of various policies, economists help policymakers evaluate their options. (Mankiw: 2004) 
Poverty alleviation is the major challenge and goal of the government of Nepal. In this context, all Nepalese people should consider about it and should involve in national economic activities. For it, Government should need to formulate goal strategies, policies and programmes to cope with growing challenges of poverty alleviation. Without increasing productivity and efficiency, we can not able to compete with global market. (Karki: 2007)

\section{Objective of Study}

The prime objective of the study is to present the current scenario of entrepreneurship development and to understand major areas of regulation of the Government for doing business. Other objective is to introduce of one village one product (OVOP) and practice of OVOP in various countries.

\section{Data Analysis}

\subsection{Doing Business 2011}

A vibrant private sector-with firms making investment, creating jobs and improving productivity-promotes growth and expands opportunities for the poor.

Doing Business 2011 is the eight in a series of annual reports benchmarking the regulation that enhance business activity and those that constrain it. The report presents quantitive indicators on business regulation and the protection of property right for 183 economies from Afghanistan to Zimbabe.

A fundamental premise of Doing Business is that economic activity requires good rules that establish and clarify property rights and reduce the cost of resolving dispute rules that increases the predictability of economic interaction and provide contractual partner with certainty and protection against abuse. The objective is regulation designed to be efficient accessible to all and simple in their implementation. Doing Business give higher scores in some area for stronger property right and investor protection such as stricter disclosure requirements in related party transactions.

Doing Business takes the perspective of domestic primarily smaller companies and measures the regulation applying to them through their life cycle. Economies are ranked on the basis of 9 area of regulation for starting a business, dealing with construction permits registering property, getting credit, protecting investors, paying taxes, trading actors borders, enforcing contracts and closing a business. (Devan: 2011)

Against the backdrop of the global financial and economic crisis, policy maker around the world took steps in the past years to make it easier for local firm to start 
up and operate. This is important. Throughout 2009/10 firms around the world felt the repercussions of what began as a financial crisis in mostly high income economies and then spread as an economic crisis to many more. While some economies have been hit harder than others, how easy or difficult it is to start and run a business and how efficient court and insolvency proceedings are can influence how firm cope with crises and how quickly they can size new opportunities.

Where is it easiest to do business? Globally, doing business remains easiest in OECD high-income economies. In sub-saharan Africa and South Asia entrepreneurs have it hardest and property protection are weakest across the 9 area of business regulation included in this year's ranking on the ease of doing business. Out of 183 economies, Singapore retains the top ranking or the ease of doing business this 4 year, followed by Hong Kong SAR (China), Newzealand, the United Kingdom, the United States, Denmark, Canada, Norway, Ireland and Australia. Nepal has ranked in 116. China and India have ranked 78 and 135 respectively.

Top-ranking economies often use risk based system to focus their resources where they matter most, such as the supervision of complex building projects. Germany and Singapore are among the 85 economies that have fast track permit application process for small commercial buildings. These economies tend to hold public servants accountable through performance based system. Australia, Singapore and the United States have used performances in the judiciary since the late 1990s. Malaysia introduced a performance index for judges in 2009. Case disposal rates are already improving. The following table present is doing business a comparison between topped ranked economies Singapore and low-income economies like Nepal.

Table 1: A comparative study between Nepal and Singapore Making a difference for Entrepreneurs

\begin{tabular}{|c|l|c|c|}
\hline \multirow{2}{*}{ S.N. Particulars } & \multicolumn{2}{|c|}{ Rank } \\
\cline { 3 - 4 } & \multicolumn{1}{|c|}{} & Nepal & Singapore \\
\hline 0 & Ease of doing Business & $\mathbf{1 1 6}$ & $\mathbf{1}$ \\
\hline 1 & Starting a business (Rank) & 96 & 4 \\
& a. Procedure (Number) & 7 & 3 \\
& b. Time (days) & 31 & 3 \\
& c. Cost (\% of income per capita) & 46.6 & 0.7 \\
& d. Minimum capital (\%of income per capita) & 0.0 & 0.0 \\
\hline
\end{tabular}




\begin{tabular}{|c|c|c|c|}
\hline \multirow[t]{4}{*}{2} & Dealing with construction permits (rank) & 130 & 2 \\
\hline & a. Procedure (Number) & 15 & 11 \\
\hline & b. Time (Days) & 424 & 25 \\
\hline & c. Cost ( $\%$ of income per capita) & 192.1 & 19.7 \\
\hline \multirow[t]{6}{*}{3} & Registering property (Rank) & 25 & 15 \\
\hline & a. Procedure (Number) & 3 & 3 \\
\hline & b. Time (Days) & 5 & 5 \\
\hline & c. Cost (\% of property value) & 4.8 & 2.8 \\
\hline & Level of Income & Low & High \\
\hline & & Income & Income \\
\hline \multirow[t]{5}{*}{4} & Getting Credit (Rank) & 89 & 6 \\
\hline & a. Strength of legal index $(0-10)$ & 6 & 10 \\
\hline & b. Depth of credit in formation index (0-6) & 2 & 4 \\
\hline & c. Public registry coverage ( $\%$ of adult) & 0.0 & 0.0 \\
\hline & d. Private bureau coverage ( $\%$ of adult) & 0.3 & 60.8 \\
\hline \multirow[t]{5}{*}{5} & Protecting investors (Rank) & 74 & 2 \\
\hline & a. Extent of disclosure index $(0-10)$ & 6 & 10 \\
\hline & b. Extent of director liability index (0-10) & 1 & 9 \\
\hline & c. Ease of share holder suit index $(0-10)$ & 9 & 9 \\
\hline & d. Strength investor protection index $(0-10)$ & 5.3 & 9.3 \\
\hline \multirow[t]{4}{*}{6} & Paying Taxes (Rank) & 123 & 4 \\
\hline & a. Payment (number of year) & 34 & 5 \\
\hline & b. Time (hours per year) & 338 & 84 \\
\hline & c. Total tax rate (\% of profit) & 38.2 & 25.4 \\
\hline \multirow[t]{7}{*}{7} & Trading across brodess (Rank) & 164 & 1 \\
\hline & a. Documents to export (number) & 9 & 4 \\
\hline & b. Time to export (days) & 41 & 5 \\
\hline & c. Cost to export (US \$ per container) & 1960 & 456 \\
\hline & d. Document to import (number) & 10 & 4 \\
\hline & e. Time to import (day) & 35 & 4 \\
\hline & f. Cost to import (US \$ per container) & 2095 & 439 \\
\hline \multirow[t]{4}{*}{8} & Enforcing Contracts (Rank) & 123 & 13 \\
\hline & a. Procedure (Number) & 39 & 21 \\
\hline & b. Time (days) & 735 & 150 \\
\hline & c. $\operatorname{Cost}(\%$ of claim $)$ & 26.8 & 25.8 \\
\hline
\end{tabular}




\begin{tabular}{|c|l|c|c|}
\hline 9 & Closing a business (Rank) & 107 & 2 \\
& a. Time day (year) & 5.0 & 0.8 \\
& b. Cost (\% of estate) & 9 & 1 \\
& c. Recovery rate (Cent on dollar) & 24.5 & 91.3 \\
\hline & GNI Per Capita (US \$) & 440 & 37280 \\
& Population (m) & 29.3 & 5.0 \\
\hline
\end{tabular}

Source: Doing Business 2011, (P-183)

The table presents a comparative study between Nepal and Singapore. Based on 9 areas of business regulation Nepal has ranked 116 whereas Singapore has ranked top one. These nine areas of business regulation are main indicators for evaluation 183 country in the world. Under these nine indicators each areas has different indicator which help to evaluate government regulation regarding operation and running of business as well as closing the business. Nepalese business sector has been faced with various problem and obstacle due to longer and unclear regulation regarding commencement, operation and running of business. In contrast of Nepal, Government of Singapore provides shortest and fastest government service to business sector. It seems that Singapore government provides appropriate environment to business community to doing business. It means business community of Singapore enjoy by ease of doing business rather than Nepalese business community.

\subsection{One Village One Product (OVOP) a movement for Entrepreneurship Development}

'Isson Ippin' meaning one village on product (OVOP) in Japanese is a community centred and demand driven rural economic development programme that originated in Oita Prefecture, one of 47 prefectures in Japan in 1979. OVOP is now a popular term of rural development in Asia followed by Africa and Latin America. China was the first nation outside Japan to adopt OVOP movement in 1980, the city of Shanghai initiated a movement with a slogan 'One Hamlet one product' OHOP.

A credit goes to Dr. Morihiko Hiramatsu, the farmer Governor of Oita prefecture, who named and promoted OVOP as a campaign with a vision of revitalizing remote villages at a time when there was a problem of depopulation due to the migration of village youngsters to big cities for seeking employment. (Shakya: 2011)

The OVOP in Japan is a cooperative village or district level movement but not a central government program. The local people of Towns and Village themselves are 
responsible for promoting OVOP with their own fund. The success or failure of the program depends upon the commitments and dedication of the local community.

\subsection{Principle of OVOP}

The OVOP movement defined by Oita OVOP international exchange promotion committee is based on the following three principles (Oita OVOP)

1. Think Globally Act Locally

2. Self-reliance and creativity

3. Human Resource Development

[Oita OVOP international exchange promotion committee, OVOP movement principles of OVOP]

It is already been 30 years since OVOP was first introduced in Oita prefecture. Today's 300 or 50 OVOP products both tangible and intangible produces Tangible produces include agricultural produces while intangible products include building facilities, cultural activities, rural development activities and conservation activities

Table 2: OVOP Products in Japan in 2002

\begin{tabular}{|l|c|}
\hline \multicolumn{1}{|c|}{ Products/Activities } & Number \\
\hline Agricultural Products & 338 \\
Building facilities & 148 \\
Cultural activities & 133 \\
Rural development activities & 111 \\
Conservation activities & 80 \\
\hline \multicolumn{1}{|c|}{ Total } & 810 \\
\hline
\end{tabular}

Source: http://www.ovop.ip/en/isonp/seika.html

\subsection{One Tambon one Product (OTOP) in Thailand}

One Tambon one product (OTOP) is a Thai version of OVOP. Tambon stands for sub-district. The OTOP is one among many Thai Government projects which aim for the development at the grass root level. The former Thai Prime Minister Thaksin Shinawatra launched OTOP in Thailand in 2001 up 2006. OTOP is considered as one the examples of successful programme under OVOP modality.

Since the OTOP idea was borrowed from Oita, Japan where village community is the focal point of the movement but, in the cause of Thailand, it is a national perspective. In other words, OTOP is a national development policy of the Thai Government. Government 
announces 'Poverty War' and made policy to promote OTOP to confront the most alarmed problem of poverty. (Shakya: 2011)

Table 3: OTOP producer Registration Year 2010

\begin{tabular}{|c|l|c|}
\hline S.N. & \multicolumn{1}{|c|}{ Categories of producers } & No. of Group \\
\hline 1 & Community occupation group & 22200 \\
\hline 2 & One-person owner & 10,303 \\
\hline 3 & Small and Medium Enterprise (SMEs) & 725 \\
\hline & \multicolumn{2}{|c|}{ Total } \\
\hline
\end{tabular}

Source: JICA Bi-monthly Report, October 2010

There are three different types of producers groups registered under OTOP. They are community occupation group; one-person owner group; and small and medium enterprises (SMEs) group and registered producer groups whereupon 33228 groups are involved.

Table 4: OTOP Product Registration Year 2010

\begin{tabular}{|c|l|c|}
\hline S.N. & \multicolumn{1}{|c|}{ Categories of Products } & No. of Product \\
\hline 1 & Food & 20,330 \\
\hline 2 & Beverage & 3,073 \\
\hline 3 & Fabrics and Dressing wear & 21,386 \\
\hline 4 & Furnishing, Decoration \& Souvenir & 31,334 \\
\hline 5 & Herbal Product & 9,050 \\
\hline & & $\mathbf{8 5 , 1 7 3}$ \\
\hline
\end{tabular}

Source: JICA - Bi-Monthly Report -2010

Similarly, a total of 85,173 products have been developed under different categories registered in 2010. The product promoted by OTOP come under five different categories. They are food beverage, fabric and dressing wear, furnishing decoration and souvenir and herbal products.

\subsection{OVOP Programme in Nepal}

The impact of OVOP has spread widely in Asian countries and Nepal could not remain untouched. As a result, Nepal Government in 2006 spelled out the enforcement of 
OVOP in Nepal through in Budget speech.

OVOP in Nepal is a public private partnership (PPP) based program which was officially launched in July 17, 2006 for 5 years as a pilot project. The program in its first year with 4 products has extended in 7 districts. In the second year of its operation the program has been extended in two new additional districts with new products. Similarly, in the fourth year, the program was successful to introduce two new products in two additional districts. The end of five year of in operation, Products in 11 districts have been extended.

During the period of 5 years, the program has basically focused on production and marketing side. Different agriculture inputs and technical training had been provided to the products for the extension of the production areas as well as quality production. Similarly, different inputs and technical training had been given to improve market and marketing system development.

Table 5: OVOP Produces in Nepal

\begin{tabular}{|c|l|l|c|}
\hline S.N. & \multicolumn{1}{|c|}{ Products } & \multicolumn{1}{c|}{ Districts } & Introduced Year \\
\hline 1 & Junar (Citrus Sinesiss (1) OSb) & Ramechhap and Sinduli & 2006 \\
\hline 2 & Lapsi (Choeropondias axillaries) & Bhaktapur & 2006 \\
\hline 3 & Bel (aegle marmelos (linn) correa) & Bardiya and Siraha & 2006 \\
\hline 4 & Rainbow Trout (ancorhynchusmykiss) & Nuwakot and Rasuwa & 2006 \\
\hline 5 & Cymbidium Orchid & Lalitpur & 2007 \\
\hline 6 & Agro Tourism & Lekhnath Kaski & 2007 \\
\hline 7 & Coffee (Coffee Arabica/ Coffee Canephora) & Syangja & 2009 \\
\hline 8 & Lokta Paper & Dolkha & 2009 \\
\hline
\end{tabular}

Source: Agro-Enterprise Bulletin, 2067

OVOP Nepal is a part of national agenda pertaining to poverty alleviation. The programme was designed more or less based on three fundamental principles of Oita Movement. Identification of potential local product, value addition, branding and the market promotion are the major objectives of the programme. The OVOP in Nepal is a PPP based programme. Ministry of Agriculture \& Cooperative (MOAC) (Public) and federation of Nepal chamber of commerce and industry (FNCCI) (private) is the major partner of the programme.

\section{Conclusion}

Through this article the author try to present two different practices in the business 
world. First, the scenario of worldwide business practice and their ranked, and second interduce a new concept and practice of one village one product (OVOP) for starting a new business. Former scenario presents doing of business in the world. Without having appropriate business environment nobody can be able to start a business in particular country. Nine different indicator apply to measure whether favourable environment is available to start a business or not in a particular nation.

Starting a business, dealing with construction permits, registering property, getting credit, protecting investors, paying taxes, trading across borders, enforcing contracts, and closing a business are main indicators which are used to evaluate whether favourable business environment is available to start a business or not. These indicator falls under ease of doing business. Out of 183 economics in the world, Nepal has ranked 116 whereas Singapore has ranked topmost.

Through OVOP, local resources, skill and human resources can be utilize and produce quality goods and service. Such goods can be sold into local market as well as national and international market and generate revenue and reduce the unemployment problems.

To promote and extent of business sector, Government should be able to provide sound business environment such as sound business friendly environment for investment and their returns, appropriate rules and regulation for security of investment, formulated adequate and appropriate strategies and policy for production of goods and services and their market etc.

World business scenario revolved that local firms are able to survive and operate smoothly within global financial and economic crisis last year. Therefore, local firms should be made strengthen with appropriate government policies like PPP and OVOP and regulation. Through it, we can be able to achieve the goal of poverty alleviation and able to solve unemployment problems. The Government must be involved to designed appropriate regulation with consider of efficient accessible to all and simple in their implementation. 


\section{REFERENCES}

Agro-Enterprise Centre - FNCCI (2067 Magh-Chaitra). Agro Enterprise Bulletin. Kathmandu: Agro Enterprise Centre- FNCCI

Devan, J. (2011). Making of a difference for entrepreneurs. Washington DC: The world Bank International Finance Corporation.

JICA. (2011). Bi-monthly Report. Kathmandu: JICA.

Karki, B.B. (2007). Role of entrepreneurship and small business in national development. The Journal of Nepalese Business Studies, IV (1): 75-82.

ManKiw., N. G. (2004). Macro economics (5 ${ }^{\text {th }}$ ed.). Kundi: Replika Press Put LTd.

The World Bank. (2011). Doing business 2011 Making a difference for entrepreneurs. Washington DC: The World Bank International Finance Corporation.

Shakya, G. (2011). Understanding one village one product in Japan, Thiland and Nepal. Kathmandu: Agro Enterprise Centre (AEC) / Japan International Cooperation Agency (JICA)

www.ovop.ip/en/isonp/seika.html 